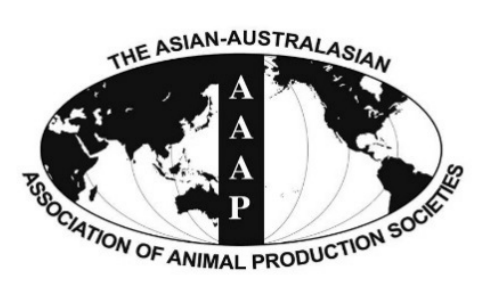

\title{
The Nutritive Values in Different Varieties of Corn Planted in One Location Fed to Growing Pigs over Three Consecutive Years
}

\author{
L. Zhang, Y. K. Li, Z. C. Li, Q. F. Li', M. B. Lyu' ${ }^{1}$, D. F. Li, and C. H. Lai* \\ State Key Laboratory of Animal Nutrition, Ministry of Agriculture Feed Industry Centre, \\ China Agricultural University, Beijing 100193, China
}

\begin{abstract}
This experiment was conducted to determine the effect of variety and planting year on the nutritive values of corn fed to growing pigs. Four corn varieties examined in this experiment were planted in the same village located in Longhua County, Heibei Province, China, in 2012, 2013, and 2014, respectively. During each year, corn was hand-harvested in early October and sun dried to about $14 \%$ moisture content. Three batches of twenty-four barrows $(33.27 \pm 4.30,31.88 \pm 2.93,34.21 \pm 3.81 \mathrm{~kg}$ body wight [BW] in 2012 , 2013, and 2014, respectively) were used and allotted to a complete block design with 4 diets and 6 replicate pigs per diet. Pigs were individually placed in metabolic crates. The four experimental diets were formulated by mixing each variety of corn and vitamins and minerals, respectively. A five-day collection period followed a seven-day diet acclimation period. The results indicated that variety of corn significantly influenced the available energy content (digestible energy [DE] on dry matter basis, $\mathrm{p}<0.05$; metabolizable energy (ME) on dry matter basis, $\mathrm{p}<0.05$, respectively), and the apparent total tract digestibility (ATTD) of organic matter ( $<<0.01$ ), dry matter $(p<0.05)$, gross energy $(p<0.05)$, neutral detergent fiber $(p<0.01)$, acid detergent fiber and ether extract $(p<0.05)$. The planting year also significantly influenced the available energy contents ( $D E$ on dry matter basis, $p<0.05$; ME on dry matter basis, $p<0.01$, respectively) and the ATTD of neutral detergent fiber $(p<0.01)$, acid detergent fiber $(p<0.01)$, crude protein $(p<0.01)$, and ether extract $(p<0.01)$. No interaction was observed between the variety and planting year in DE and ME contents in corn. In conclusion, the variety and planting year significantly influenced the available energy and nutrient digestibility of corn fed to growing pigs. (Key Words: Corn, Digestible Energy, Variety, Pigs, Planting Year)
\end{abstract}

\section{INTRODUCTION}

Corn is the primary source of energy in pig diets in many countries. The amount of energy in corn used for maintenance and growth of pigs is not constant mainly due to variations in chemical composition ( $\mathrm{Li}$ et al., 2014a). Factors influencing the chemical composition of corn include variety, planting location, drying method, storage duration, and planting year (Genter et al., 1956; Jellum and Marion, 1966; Peplinski et al., 1989; Leeson et al., 1993; Rehman et al., 2002; Iji et al., 2003).

Although the high-oil (Adeola and Bajjalieh, 1997;

\footnotetext{
* Corresponding Author: C. H. Lai. Tel: +86-10-6273-4403, Fax:+86-10-6273-3688, E-mail: laichanghua999@163.com

${ }^{1}$ New Hope Liuhe Co., Ltd., Beijing, 100102, China.

Submitted Jan. 18, 2016; Revised Mar. 6, 2016; Accepted Mar. 16, 2016
}

Song et al., 2003) and high-lysine (Sihombing et al., 1969) corn varieties contain greater nutritive values than conventional yellow dent corn fed to growing pigs, these varieties have other applications, such as corn oil production and Health care products production and the planting area in China is actually limited. Thus the main types of corn used in feeds remain the conventional varieties. Some experiments had been conducted to compare the nutritive value of different varieties of corn fed to growing pigs using conventional corn varieties (Fent et al., 2000; Moore et al., 2008; Li et al., 2014b). In a previous study (Li et al., 2014b), we had found that soft variety corn (LS1) contained greater digestible energy (DE) value than hard variety corn (LS3) and intermediate hardness corn (LS2; LS4) when fed to growing pigs. Although these varieties were grown at the same location, it is still uncertain whether soft corn variety LS1 had a greater 
available energy than the other varieties in subsequent planting years. Some studies indicated that the chemical composition and concomitant nutritive value of corn for chickens were variable with different planting years (Connor et al., 1976). Data comparing nutritive values of corn with planting year is lacking in pigs.

Therefore, the objectives of this experiment were to compare the nutritive values for four representative conventional corn varieties over three consecutive years and to determine the influence of planting year on the nutritive value of corn.

\section{MATERIALS AND METHODS}

The China Agricultural University Laboratory Animal Welfare and Animal Experimental Ethical Inspection Committee (Beijing, China) reviewed and approved all protocols used in this experiment.

\section{Selection and preparation of the corn samples}

Four corn varieties were grown at one location, a village in the north of China, in 2012, 2013 and 2014. All these varieties were conventional varieties, and representative varieties widely planted in the north of China. According to the differences of hardness, the corn were classified as soft (LS1), hard (LS3), and two intermediate hardness (LS2; LS4). The harvest was carried out in early October in each of the three years. Table 1 is the meteorological index over three growing seasons at the planting area. During each year, four corn varieties were sun dried to about $14 \%$ moisture content.

\section{Animals, housing, and experimental design}

After the corn was dried (early November), twenty-four barrows (Duroc $\times$ Landrace $\times$ Yorkshire; 2012: initial body wight $[\mathrm{BW}]=33.27 \pm 4.30 \mathrm{~kg} ;$ 2013: initial $\mathrm{BW}=$
Table 2. Ingredient composition of the experimental diets in 2012, 2013, or 2014 (as-fed basis)

\begin{tabular}{lc}
\hline Ingredients (\%) & Experimental diet \\
\hline Corn & 96.8 \\
Antioxidant $^{1}$ & 0.1 \\
Dicalcium phosphate & 1.7 \\
Limestone & 0.6 \\
Salt & 0.3 \\
Vitamin and mineral premix $^{2}$ & 0.5
\end{tabular}

${ }^{1}$ Santoquin MAX composite antioxidant, contained no less than $10 \%$ ethoxyquin, no less than $3 \%$ butylatedHydroxytoluene and citric acid, provided by Novus International, International, Inc.

${ }^{2}$ Premix provided the following per $\mathrm{kg}$ of complete diet: vitamin A, 5,512 IU; vitamin $\mathrm{D}_{3}$, 2,200 IU; vitamin E, $30 \mathrm{IU}$; vitamin $\mathrm{K}_{3}, 2.2 \mathrm{mg}$; vitamin $\mathrm{B}_{12}, 27.6 \mu \mathrm{g}$; riboflavin, $4 \mathrm{mg}$; pantothenic acid, $14 \mathrm{mg}$; niacin, $30 \mathrm{mg}$; choline chloride, $400 \mathrm{mg}$; folic acid, $0.7 \mathrm{mg}$; thiamin, $1.5 \mathrm{mg}$; pyridoxine, $3 \mathrm{mg}$; biotin, $44 \mu \mathrm{g}$; $\mathrm{Mn}, 40 \mathrm{mg}\left(\mathrm{MnSO}_{4}\right) ; \mathrm{Fe}, 75 \mathrm{mg}$ $\left(\mathrm{FeSO}_{4} \cdot \mathrm{H}_{2} \mathrm{O}\right) ; \mathrm{Zn}, 75 \mathrm{mg}\left(\mathrm{ZnSO}_{4}\right) ; \mathrm{Cu}, 100 \mathrm{mg}\left(\mathrm{CuSO}_{4} \cdot 5 \mathrm{H}_{2} \mathrm{O}\right) ; \mathrm{I}, 0.3 \mathrm{mg}$ (KI); $\mathrm{Se}, 0.3 \mathrm{mg}\left(\mathrm{Na}_{2} \mathrm{SeO}_{3}\right)$.

$31.88 \pm 2.93 \mathrm{~kg} ;$ 2014: initial $\mathrm{BW}=34.21 \pm 3.81 \mathrm{~kg}$ ) were individually housed in stainless-steel metabolism crates $(1.4 \times 0.7 \times 0.6 \mathrm{~m})$ at the Fengning Swine Research Unit of China Agricultural University (Hebei, China). A feeder and a nipple drinker were installed in each pen. The crates were located in a room with temperature maintained at $22^{\circ} \mathrm{C} \pm 1^{\circ} \mathrm{C}$. In each of three years, pigs were allotted to one of four diets according to a completely randomized design, and each diet was fed to six pigs.

\section{Diets, feeding, and sample collection}

In 2012, 2013, and 2014, four diets were formulated to contain $96.8 \%$ of each corn variety and $3.2 \%$ other ingredients including vitamins and minerals (Table 2). All diets were fed in mash form. Corn was included as the sole energy and protein source in the diet, and vitamins, minerals and salt were added to meet or exceed the estimated requirements for growing pigs (NRC, 1998).

Table 1. The meteorological index over three growing seasons at the planting area

\begin{tabular}{|c|c|c|c|c|c|c|c|}
\hline \multirow{2}{*}{ Item } & & \multicolumn{6}{|c|}{ Meteorological index ${ }^{1}$} \\
\hline & & May & June & July & August & September & October \\
\hline \multirow[t]{4}{*}{2012} & Sunshine duration (h) & 285.4 & 167.6 & 219.4 & 249.7 & 218.5 & 247.2 \\
\hline & Temperature $\left({ }^{\circ} \mathrm{C}\right)$ & 17.8 & 19.3 & 23.3 & 21.4 & 15.1 & 7.7 \\
\hline & Relative humidity (\%) & 43 & 73 & 69 & 67 & 65 & 55 \\
\hline & Rainfall (mm) & 28.1 & 153.3 & 107.2 & 44.4 & 41 & 33.1 \\
\hline \multirow[t]{4}{*}{2013} & Sunshine duration (h) & 276.5 & 170.2 & 245.4 & 221.7 & 198.2 & 206 \\
\hline & Temperature $\left({ }^{\circ} \mathrm{C}\right)$ & 17.8 & 20.3 & 23.4 & 22.7 & 15.2 & 7.7 \\
\hline & Relative humidity (\%) & 44 & 68 & 69 & 69 & 69 & 66 \\
\hline & Rainfall (mm) & 13.2 & 83.6 & 102.4 & 104 & 49.7 & 43.6 \\
\hline \multirow[t]{4}{*}{2014} & Sunshine duration (h) & 267.1 & 241.5 & 235.6 & 243.7 & 206.6 & 169.2 \\
\hline & Temperature $\left({ }^{\circ} \mathrm{C}\right)$ & 16.2 & 20.6 & 23.9 & 20.8 & 15.4 & 8.6 \\
\hline & Relative humidity (\%) & 46 & 63 & 63 & 68 & 68 & 64 \\
\hline & Rainfall (mm) & 65.2 & 80.9 & 94.6 & 164 & 67.3 & 33.9 \\
\hline
\end{tabular}

${ }^{1}$ All of these meteorological data were collected from the local meteorological bureau. 
Feed was provided in equal amounts twice daily, at 0800 and $1700 \mathrm{~h}$. Water was available continuously for each pig. During the adjustment period to the metabolism crates and diets, average daily feed intake was gradually increased until it was estimated to supply $4 \%$ of the BW determined at the initiation of each adaptation period. During the collection period, all fresh fecal samples were collected as often as possible throughout the day and were stored at $-20^{\circ} \mathrm{C}$. The collection and sample preparation of feces and urine were conducted according to the methods described by Li et al. (2015).

\section{Chemical analyses}

At the end of the animal experiment, fecal samples were dried at $60^{\circ} \mathrm{C}$ in a forced-air oven for $72 \mathrm{~h}$, and then were finely ground. Diets and feces were analyzed for dry matter (DM) (AOAC, 2000), ether extract (EE) (Thiex et al., 2003) and ash (AOAC, 2000). Kjeldahl $\mathrm{N}$ was determined according to the method of Thiex et al. (2002). Diet and fecal samples were analyzed for neutral detergent fiber (NDF) and acid detergent fiber (ADF) by using filter bags and fiber analyzer equipment (Fiber Analyzer, Ankom Technology, Macedon, NY, USA) following a modification of the procedure of Van Soest et al. (1991). Starch was determined after converting starch to glucose using an enzyme assay kit (Megazym International Ireland, Wicklow, Ireland). The gross energy (GE) of urine was measured by applying $4 \mathrm{~mL}$ of urine sample onto 2 filter papers in a special crucible manufactured by Parr Instrument Company and then dried for $8 \mathrm{~h}$ in a $65^{\circ} \mathrm{C}$ drying oven. The GE of feces and diets were measured using an isoperibol oxygen bomb calorimeter (Parr 6400 Calorimeter, Moline, IL, USA).

\section{Calculations and statistical analyses}

Energy values determined from the GE in the feces and urine were subtracted from the intake of GE to calculate DE and metabolizable energy (ME) for each diet. The apparent total tract digestibility (ATTD) of chemical constituents determined from the excretion of chemical constituents in the feces were first subtracted from the intake of the chemical constituents then were divided by the intake of the chemical constituents to calculate the ATTD of the chemical constituents for each diet and corn (Kong and Adeola, 2014). The DE and ME in the corn diets were divided by 0.968 to calculate the DE and ME of the corn itself.

Data were analyzed as a randomized complete block design by using PROC general linear model of SAS (SAS Inst. Inc., Cary, NC, USA) with pig as the experimental unit. Main effects of variety and planting year interactions were tested. Means were separated using the least squared means procedure and the PDIFF option of SAS. The alpha level of 0.05 was used to assess the significance of difference between means. The proximate chemical composition, GE, $\mathrm{DE}$, and $\mathrm{ME}$ of corn, sunshine duration, and rainfall were correlated using PROC CORR of SAS.

\section{RESULTS}

\section{Chemical composition of corn}

The chemical compositions of four corn varieties over three consecutive years are presented in Table 3. The average concentration of DM in 12 corn samples pooled in 2012, 2013, and 2014 were $86.46 \%$, ranging from $85.14 \%$ to $88.49 \%$. On a DM basis, the concentrations of starch, EE, $\mathrm{NDF}$, ADF, crude protein (CP), ash, and GE averaged $73.06 \%(71.41 \%$ to $74.42 \%), 4.15 \%(3.33 \%$ to $5.53 \%)$, $13.14 \%(10.72 \%$ to $15.34 \%), 2.52 \%(2.05 \%$ to $2.97 \%)$, $8.66 \%$ ( $8.13 \%$ to $9.31 \%), 1.32 \%$ (1.19\% to $1.51 \%)$, and $18.48 \mathrm{MJ} / \mathrm{kg}(18.19 \%$ to $18.62 \mathrm{MJ} / \mathrm{kg})$, respectively. The coefficient of variation (CV) of 12 corn samples for starch, $\mathrm{CP}$, ash, and GE were within $10 \%$, but wide variations in the content of EE (CV: $16.60 \%)$, NDF (CV: 10.68\%) and ADF (CV: $14.43 \%)$. In this experiment, variety and planting year are the major sources of variations in the chemical composition.

\section{Energy content and the nutrient digestibility of corn}

The DE and ME contents of the 12 corn samples and ATTD of nutrients are presented in Table 4. The interaction between variety and planting year was not significant except the ATTD of GE $(\mathrm{p}<0.05), \operatorname{ADF}(\mathrm{p}<0.01)$ and CP $(p<0.01)$. Variety LS1 had a higher $(p<0.05)$ DE than other corn varieties (LS2, LS3, and LS4); no differences among LS2, LS3, and LS4 were observed. The ATTD of organic matter (OM), DM, GE, NDF, and ADF was also greater $(\mathrm{p}<0.05)$ in LS1 than in LS2, LS3, and LS4. The DE and ME contents in 2012 was greater $(\mathrm{p}<0.05)$ than in 2013 and 2014; no differences between 2013 and 2014 were found. The ATTD of NDF, ADF in 2014 was lower $(p<0.01)$ than that in 2012 and 2013; however, the ATTD of CP in 2014 was greater $(p<0.01)$ than that in 2012 and 2013. The ATTD of EE in 2012 was greater $(p<0.01)$ than in 2013 , and the ATTD of EE in 2013 was greater $(p<0.01)$ than in 2014.

\section{Correlations of parameters that determine DE and ME}

Correlations of parameters that determine $\mathrm{DE}$ and $\mathrm{ME}$ are presented in Table 5. The content of NDF had a significant negative correlation with $\mathrm{DE}$ and $\mathrm{ME}$ contents $(\mathrm{r}$ $=-0.63 ; \mathrm{p}<0.05 ; \mathrm{r}=-0.81 ; \mathrm{p}<0.01$, respectively). The content of $\mathrm{EE}$ had a significant negative correlation with ME $(r=-0.63 ; p<0.01)$. The sunshine duration (July, August, and September) was significantly positively correlated with ME $(r=0.58 ; p<0.05)$. And the content of GE was also significantly positively correlated with ME ( $r$ 
Table 3. Chemical composition (dry matter basis, \%) of corn samples ${ }^{1}$

\begin{tabular}{clcccccccc}
\hline $\begin{array}{c}\text { Planting } \\
\text { year }\end{array}$ & Variety & Dry matter & Starch & $\begin{array}{c}\text { Ether } \\
\text { extract }\end{array}$ & $\begin{array}{c}\text { Neutral } \\
\text { detergent fiber }\end{array}$ & $\begin{array}{c}\text { Acid } \\
\text { detergent fiber }\end{array}$ & Crude protein & $\begin{array}{c}\text { Ash } \\
\text { Gross energy } \\
(\mathrm{MJ} / \mathrm{kg})\end{array}$ \\
\hline 2012 & LS1 & 85.35 & 73.26 & 3.70 & 10.72 & 2.48 & 9.13 & 1.47 & 18.61 \\
& LS2 & 85.93 & 72.51 & 3.72 & 12.20 & 2.65 & 8.27 & 1.36 & 18.62 \\
& LS3 & 85.14 & 72.95 & 3.72 & 12.07 & 2.63 & 8.62 & 1.31 & 18.59 \\
& LS4 & 86.30 & 74.38 & 3.53 & 11.42 & 2.46 & 8.81 & 1.28 & 18.49 \\
& Mean & 85.68 & 73.28 & 3.67 & 11.60 & 2.56 & 8.71 & 1.36 & 18.58 \\
& CV & 0.62 & 1.09 & 2.51 & 5.86 & 3.87 & 4.13 & 6.16 & 0.32 \\
2013 & LS1 & 85.57 & 71.41 & 5.31 & 12.74 & 2.94 & 8.14 & 1.38 & 18.56 \\
& LS2 & 85.98 & 72.01 & 4.60 & 14.30 & 2.88 & 8.18 & 1.19 & 18.58 \\
& LS3 & 85.76 & 73.01 & 5.53 & 15.34 & 2.97 & 8.13 & 1.30 & 18.33 \\
& LS4 & 85.21 & 73.15 & 4.34 & 13.35 & 2.87 & 8.56 & 1.51 & 18.19 \\
& Mean & 85.63 & 72.40 & 4.95 & 13.93 & 2.92 & 8.25 & 1.35 & 18.42 \\
& CV & 0.38 & 1.15 & 11.44 & 8.16 & 1.65 & 2.50 & 10.02 & 1.02 \\
& LS1 & 87.75 & 73.40 & 4.06 & 14.99 & 2.07 & 8.51 & 1.27 & 18.45 \\
& LS2 & 87.66 & 73.03 & 3.83 & 13.38 & 2.09 & 9.18 & 1.25 & 18.49 \\
& LS3 & 88.49 & 73.19 & 4.17 & 13.06 & 2.10 & 9.12 & 1.37 & 18.47 \\
& LS4 & 88.34 & 74.42 & 3.33 & 14.12 & 2.05 & 9.31 & 1.20 & 18.32 \\
& Mean & 88.06 & 73.51 & 3.85 & 13.89 & 2.08 & 9.03 & 1.27 & 18.43 \\
& CV & 0.47 & 0.85 & 9.69 & 6.18 & 1.07 & 3.94 & 5.61 & 0.42 \\
\hline
\end{tabular}

$\mathrm{CV}$, coefficient of variation.

${ }^{1}$ All data are the results of a chemical analysis conducted in duplicate.

$=0.57 ; \mathrm{p}<0.05)$

\section{DISCUSSION}

Comparison of nutritive values among four varieties of corn

Among four varieties of corn, variety LS1 had the highest DE and ME contents over three consecutive years. The ATTD of OM, DM, GE, NDF, and ADF was also greater in LS1 than in LS2, LS3, and LS4. When compared among three planting years, the DE and ME contents in 2012 was greater than in 2013 and 2014. And no interaction between variety and planting year in DE and ME contents was found. All these results showed that although the DE and ME contents significantly varied from year to year, the LS1 had higher DE and ME contents than all other corn in these three years. The results provide a probability that the rank of varieties in $\mathrm{DE}$ and $\mathrm{ME}$ contents is going to be stable in one area in subsequent years. It should be possible to grow certain varieties of conventional corn containing greater $\mathrm{DE}$ and $\mathrm{ME}$ when fed to growing pigs in that location.

\section{Effect of planting year on the nutritive value of corn}

From Table 4, the DE and ME contents in 2012 were greater than in 2013 and 2014; while no differences between 2013 and 2014 were observed. According to Table 3, the starch, EE, NDF, ADF, CP, and GE contents were

Table 4. Effect of variety and planting year on the nutritive value of corns fed to growing pigs

\begin{tabular}{|c|c|c|c|c|c|c|c|c|c|c|c|}
\hline \multirow{2}{*}{ Item } & \multicolumn{4}{|c|}{ Variety } & \multicolumn{3}{|c|}{ Planting year } & \multirow{2}{*}{ SEM } & \multicolumn{3}{|c|}{ p-value } \\
\hline & LS1 & LS2 & LS3 & LS4 & 2012 & 2013 & 2014 & & $\mathrm{~V}^{2}$ & $\mathrm{PL}$ & $\mathrm{V} \times \mathrm{PL}$ \\
\hline $\begin{array}{l}\text { Digestible energy } \\
(\mathrm{MJ} / \mathrm{kg} \text { of } \mathrm{DM})\end{array}$ & $16.38^{\mathrm{a}}$ & $16.13^{b}$ & $16.17^{\mathrm{b}}$ & $16.16^{\mathrm{b}}$ & $16.33^{\mathrm{a}}$ & $16.15^{\mathrm{b}}$ & $16.14^{\mathrm{b}}$ & 0.12 & $<0.05$ & $<0.05$ & 0.25 \\
\hline $\begin{array}{l}\text { Metabolizable energy } \\
(\mathrm{MJ} / \mathrm{kg} \text { of } \mathrm{DM})\end{array}$ & $15.99^{\mathrm{a}}$ & $15.73^{\mathrm{ab}}$ & $15.61^{\mathrm{b}}$ & $15.75^{\mathrm{ab}}$ & $16.09^{\mathrm{a}}$ & $15.53^{\mathrm{b}}$ & $15.69^{\mathrm{b}}$ & 0.17 & $<0.05$ & $<0.01$ & 0.14 \\
\hline \multicolumn{12}{|c|}{ Digestibility coefficients (\%) } \\
\hline Organic matter & $91.13^{\mathrm{a}}$ & $89.67^{\mathrm{b}}$ & $89.98^{\mathrm{b}}$ & $90.39^{\mathrm{ab}}$ & 90.24 & 90.27 & 90.37 & 0.52 & $<0.01$ & 0.93 & 0.06 \\
\hline Dry matter & $89.50^{\mathrm{a}}$ & $88.03^{\mathrm{b}}$ & $88.39^{\mathrm{b}}$ & $88.78^{\mathrm{ab}}$ & 88.65 & 88.54 & 88.83 & 0.57 & $<0.05$ & 0.77 & 0.06 \\
\hline Gross energy & $88.64^{\mathrm{a}}$ & $87.27^{\mathrm{b}}$ & $87.47^{\mathrm{b}}$ & $88.06^{\mathrm{ab}}$ & 88.02 & 87.79 & 87.77 & 0.62 & $<0.05$ & 0.82 & $<0.05$ \\
\hline Neutral detergent fiber & $55.65^{\mathrm{a}}$ & $47.25^{\mathrm{c}}$ & $52.96^{\mathrm{ab}}$ & $48.05^{\mathrm{bc}}$ & $52.29^{\mathrm{a}}$ & $55.11^{\mathrm{a}}$ & $45.53^{\mathrm{b}}$ & 3.17 & $<0.01$ & $<0.01$ & 0.08 \\
\hline Acid detergent fiber & $48.47^{\mathrm{a}}$ & $36.94^{b}$ & $41.45^{b}$ & $30.32^{\mathrm{c}}$ & $48.54^{\mathrm{a}}$ & $46.37^{\mathrm{a}}$ & $22.97^{\mathrm{b}}$ & 3.68 & $<0.01$ & $<0.01$ & $<0.01$ \\
\hline Crude protein & 80.98 & 78.79 & 78.28 & 80.05 & $78.99^{b}$ & $77.18^{\mathrm{b}}$ & $82.40^{\mathrm{a}}$ & 1.54 & 0.14 & $<0.01$ & $<0.01$ \\
\hline Ether extract & $44.33^{\mathrm{b}}$ & $45.78^{\mathrm{ab}}$ & $51.39^{\mathrm{a}}$ & $48.50^{\mathrm{ab}}$ & $59.18^{\mathrm{a}}$ & $50.09^{\mathrm{b}}$ & $33.23^{\mathrm{c}}$ & 3.28 & $<0.05$ & $<0.01$ & 0.07 \\
\hline
\end{tabular}

SEM, standard error of mean; V, variety; PL, planting year; DM, dry matter. 
Table 5. Correlations of parameters determining digestible energy and metabolizable energy in 12 corn samples

\begin{tabular}{|c|c|c|c|c|c|c|c|c|c|c|c|}
\hline Item & $\mathrm{DE}^{1}$ & $\mathrm{ME}$ & $\mathrm{NDF}$ & $\mathrm{ADF}$ & $\mathrm{CP}$ & $\mathrm{EE}$ & Ash & Starch & Sun & Rainfall & $\mathrm{GE}$ \\
\hline$\overline{\mathrm{DE}}$ & 1.00 & & & & & & & & & & \\
\hline $\mathrm{ME}$ & $0.87 * *$ & 1.00 & & & & & & & & & \\
\hline $\mathrm{NDF}$ & $-0.63 *$ & $-0.81 * *$ & 1.00 & & & & & & & & \\
\hline $\mathrm{ADF}$ & 0.03 & -0.18 & -0.02 & 1.00 & & & & & & & \\
\hline $\mathrm{CP}$ & 0.19 & 0.33 & -0.31 & $-0.80 * *$ & 1.00 & & & & & & \\
\hline $\mathrm{EE}$ & -0.30 & $-0.63^{*}$ & 0.48 & $0.67 *$ & $-0.71 * *$ & 1.00 & & & & & \\
\hline Ash & 0.43 & 0.36 & -0.48 & 0.32 & -0.03 & 0.12 & 1.00 & & & & \\
\hline Starch & -0.08 & 0.07 & -0.06 & $-0.61^{*}$ & $0.68^{*}$ & $-0.65^{*}$ & -0.17 & 1.00 & & & \\
\hline Sun & 0.28 & $0.58 *$ & -0.46 & $-0.77 * *$ & $0.67 *$ & $-0.85 * *$ & -0.13 & $0.57 *$ & 1.00 & & \\
\hline Rainfall & -0.47 & -0.51 & $0.68 *$ & $-0.58 *$ & 0.33 & 0.09 & -0.36 & 0.13 & -0.04 & 1.00 & \\
\hline GE & 0.47 & $0.57^{*}$ & -0.53 & 0.03 & -0.12 & -0.16 & -0.12 & -0.42 & 0.36 & -0.45 & 1.00 \\
\hline
\end{tabular}

$\mathrm{DE}$, digestible energy; ME, metabolizable energy; NDF, neutral detergent fiber; $\mathrm{ADF}$, acid detergent fiber; $\mathrm{CP}$, crude protein; $\mathrm{EE}$, ether extract; GE, gross energy.

$*, * * \mathrm{p}<0.05, \mathrm{p}<0.01$, respectively.

variable in these three years. The lower DE and ME in 2013 and 2014 than in 2012 may be the result of higher NDF and lower GE in 2013 and 2014 than in 2012 (Noblet and Perez, 1993; Li et al., 2014a). One reason for the variation in chemical composition of corn is the difference in climatic conditions. According to Table 1, the sunshine duration, average temperature, relative humidity and rainfall were variable in the three growing seasons. Some reports indicate that starch, CP and EE contents are significantly influenced by sunshine duration, rainfall and average temperature in growing seasons (Genter et al., 1956; Thompson et al., 1973; Leeson and Summers, 1976). Another reason for the variable available energy of corn from year to year is the different moisture content of corn at harvest. Although corn was harvested at the same time in each of planting years, the initial moisture varied significantly from year to year due to different weather conditions in both growing and harvesting periods. In 2012 corn was harvested at $20 \%$ to $25 \%$ moisture content, in 2013 at $27 \%$ to $37 \%$ moisture content, in 2014 at $26 \%$ to $33 \%$ moisture content. The moisture levels of corn at harvest could represent the stage of kernel maturity (Leeson and Summers, 1976; Leeson et al., 1977). The ME of corn fed to adult roosters is negatively correlated with the moisture levels of corn at harvest (Leeson and Summers, 1976; Leeson et al., 1977). In addition, another possible explanation for the variable $\mathrm{DE}$ and ME of corn from year to year is differences in the agronomic practices used, such as irrigation and $\mathrm{N}$ fertilization. Some reports indicate that irrigation and $\mathrm{N}$ fertilization could influence the protein and lysine content of normal corn (Cromwell et al., 1983; Kniep and Mason, 1991). The experiment conducted by Cromwell et al. (1983) suggested that $\mathrm{N}$ fertilization of normal corn, while increasing its protein and lysine content, has no beneficial effect on its nutritive value for chicks.

\section{Correlations of parameters that determine DE and ME}

Correlations of parameters that determine DE and ME contents of 12 corn samples are presented in Table 5. From Table 5, the sunshine duration and GE contents were significantly positively correlated with ME, but the NDF content was significantly negatively correlated with DE and ME contents. These results are in agreement with those reported by $\mathrm{Li}$ et al. (2014a). The EE content was significantly negatively correlated with ME content, which is not in line with the data of Li et al. (2014a). According to Table 3, the EE content in 2013 was greater than in 2012 and 2014. However, from Table 4, the DE and ME contents in 2013 were lower than in 2012; while no differences between 2013 and 2014 were observed. The factors determining the DE and ME were not only the EE content, since other chemical composition differences, such as NDF, $\mathrm{ADF}, \mathrm{CP}$, starch, also correlated with the $\mathrm{DE}$ and $\mathrm{ME}$ contents. These differences may be the reason for the disagreement between our findings and those reported by $\mathrm{Li}$ et al. (2014a). Interestingly, the sunshine duration (July, August and September) was positively correlated with DE, $\mathrm{ME}$ and starch contents while the rainfall (July, August, and September) was negatively correlated with DE and ME contents, but positively correlated with NDF content. Such data provides the possibility that we can predict the DE and ME contents according to the rainfall and sunshine duration in a specific location.

\section{CONCLUSION}

In conclusion, the DE and ME contents of corn fed to growing pigs will vary significantly from year to year, but the rank of varieties will be quite similar in different planting years. It is possible that certain corn varieties containing higher DE and ME contents in one year will still contain higher $\mathrm{DE}$ and $\mathrm{ME}$ contents to be fed to growing 
pigs in a specific location in subsequent planting years. As more conventional corn varieties are studied, it should be possible to grow certain corn varieties containing higher DE and $\mathrm{ME}$ contents to be fed to growing pigs in a specific location.

\section{CONFLICT OF INTEREST}

We certify that there is no conflict of interest with any financial organization regarding the material discussed in the manuscript.

\section{ACKNOWLEDGMENTS}

This research was financially supported by the Special Public Sector Fund in Agriculture (200903006) and National Natural Science Foundation of China (31372316).

\section{REFERENCES}

Adeola, O. and N. L. Bajjalieh. 1997. Energy concentration of high-oil corn varieties for pigs. J. Anim. Sci. 75:430-436.

AOAC (Association of Official Analytical Chemists) International. 2000. Official Methods of Analysis. 17th edn. AOAC Int., Arlington, VA, USA.

Connor, J. K., A. R. Neill, and K. M. Barram. 1976. The metabolizable energy content for the chicken of maize and sorghum grain hybrids grown at several geographical regions. Aust. J. Exp. Agric. Anim. Husb. 16:699-703.

Cromwell, G. L., M. J. Bitzer, T. S. Stahly, and T. H. Johnson. 1983. Effects of soil nitrogen fertility on the protein and lysine content and nutritional value of normal and opaque-2 corn. J. Anim. Sci. 57:1345-1351.

Fent, R. W., S. D. Carter, B. W. Senne, and M. J. Rincker. 2000. Determination of the metabolizable energy concentration of three corn hybrids fed to growing pigs. Okla. Aes. Res. Rep. 980:123-128

Genter, C. F., J. F. Eheart, and W. N. Linkous. 1956. Effects of location, hybrid, fertilizer, and rate of planting on the oil and protein contents of corn grain. Agron. J. 48:63-67.

Iji, P. A., K. Khumalo, S. Slippers, and R. M. Gous. 2003. Intestinal function and body growth of broiler chickens on diets based on maize dried at different temperatures and supplemented with a microbial enzyme. Reprod. Nutr. Dev. 43:77-90.

Jellum, M. D. and J. E. Marion. 1966. Factors affecting oil content and oil composition of corn (Zea mays L.) grain. Crop Sci. 6:41-42.

Kniep, K. R. and S. C. Mason. 1991. Lysine and protein content of normal and opaque- 2 maize grain as influenced by irrigation and nitrogen. Crop Sci. 31:177-181.

Kong, C. and O. Adeola. 2014. Invited review: Evaluation of amino acid and energy utilization in feedstuff for swine and poultry diets. Asian Australas J. Anim. Sci. 27:917-925.

Leeson, S. and J. D. Summers. 1976. Effect of adverse growing conditions on corn maturity and feeding value for poultry. Poult. Sci. 55:588-593.
Leeson, S., A. Yersin, and L. Volker. 1993. Nutritive value of the 1992 corn crop. J. Appl. Poult. Res. 2:208-213.

Leeson, S., J. D. Summers, and T. B. Daynard. 1977. The effect of kernel maturity at harvest as measured by moisture content, on the metabolizable energy value of corn. Poult. Sci. 56:154-156.

Li, P., D. F. Li, H. Y. Zhang, Z. C. Li, P. F. Zhao, Z. K. Zeng, X. $\mathrm{Xu}$, and X. S. Piao. 2015. Determination and prediction of energy values in corn distillers dried grains with solubles sources with varying oil content for growing pigs. J. Anim. Sci. 93:3458-3470.

Li, Q. F., J. J. Zang, D. W. Liu, X. S. Piao, C. H. Lai, and D. F. Li. 2014a. Predicting corn digestible and metabolizablble energy content from its chemical composition in growing pigs. J. Anim. Sci. Biotechnol. 5:11.

Li, Q. F., M. Shi, C. X. Shi, D. W. Liu, X. S. Piao, D. F. Li, and C. H. Lai. 2014b. Effect of variety and drying method on the nutritive value of corn for growing pigs. J. Anim. Sci. Biotechnol. 5:18.

Moore, S. M., K. J. Stalder, D. C. Beitz, C. H. Stahl, W. A. Fithian, and K. Bregendahl. 2008. The correlation of chemical and physical corn kernel traits with growth performance and carcass characteristics in pigs. J. Anim. Sci. 86:592-601.

NRC (National Research Council). 1998. Nutrient Requirements of Swine. 10th edn. National Academy Press, Washington, DC, USA.

Noblet, J. and J. M. Perez. 1993. Prediction of digestibility of nutrients and energy values of pig diets from chemical analysis. J. Anim. Sci. 71:3389-3398.

Peplinski, A. J., M. R. Paulsen, R. A. Anderson, and W. F. Kwolek. 1989. Physical, chemical, and Dry-milling characteristics of corn hybrids from various genotypes. Cereal Chem. 66:117120

Rehman, Z. U., F. Habib, and S. I. Zafar. 2002. Nutritional changes in maize (Zea mays) during storage at three temperatures. Food Chem. 77:197-201.

Sihombing, D. T. H., G. L. Cromwell, and V. W. Hays. 1969. Nutritive value and digestibility of opaque-2 and normal corn for growing pigs. J. Anim. Sci. 29:921-926.

Song, G. L., D. F. Li, X. S. Piao, F. Chi, and W. J. Yang. 2003. Apparent ileal digestibility of amino acids and the digestible and metabolizable energy content of high-oil corn varieties and its effects on growth performance of pigs. Arch. Anim. Nutr. 57:297-306.

Thiex, N. J., H. Manson, S. Anderson, and J. A. Persson. 2002. Determination of crude protein in animal feed, forage, grain, and oilseeds by using block digestion with copper catalyst and steam distillation into boric acid: Collaborative study. J. AOAC Int. 85:309-317.

Thiex, N. J., S. Anderson, and B. Gildemeister. 2003. Crude fat, diethyl ester extraction, in feed, cereal grain, and forage (Randall/Soxtec/submersion method): Collaborative study. J. AOAC Int. 86:888-898.

Thompson, D. L., M. D. Jellum, and C. T. Young. 1973. Effect of controlled temperature environments on oil content and on fatty acid composition of corn oil. J. Am. Oil Chem. Soc. 50:540-542.

Van Soest, P. J., J. B. Robertson, and B. A. Lewis. 1991. Methods for dietary fiber, neutral detergent fiber, and nonstarch polysaccharides in relation to animal nutrition. J. Dairy Sci. 74:3568-3597. 